\title{
The Muslim Brotherhood
}

\author{
Rickard Lagervall
}

\section{1 \\ Introduction}

The Muslim Brotherhood, founded in Egypt in 1928 by the schoolteacher Hasan al-Bannā, is one of the most controversial Islamic movements. Evaluations of it range from descriptions of it as an extremist movement and a fundamental threat to an important vehicle for democratic transition in Middle Eastern states. These various judgements depend to a large degree on underlying assumptions of what religion, and specifically Islam, is, what constitutes democracy, and what role ideology plays in historical processes.

Some authors, who emphasise the role of ideas for historical change, assume that Islam in itself conflates religion and politics (Johnson 2010: 6). From that assumption there is a small step to the notion that an ideology based on Islam is essentially stable through time and place and that the Muslim Brotherhood's goals can best be found in the writings of its founder Hasan al-Bannā, most notably in the movement's slogan "Islam is the solution" (Besson 2005: 13). An understanding of the term 'Islamism' as a relatively stable and unified category tends to lead to a dismissal of the Brotherhood's rejection of violence and its political participation, as well as its differences with jihädi groups, as pure tactics (Vidino 2010: 17). If this is combined with an understanding of democracy as not only a set of rules for regulating political dissent, but as a set of values and virtues within individual citizens, the conclusion is close at hand that the eventual electoral victory of Brotherhood parties would inevitably mean the end of any democratic transition.

Authors who emphasise practice over ideology, and processes over ideological consistency, tend to be more open to the possibility of reform within the Brotherhood (Lia 20o6: 297). This appears even more credible when the Brotherhood leaders' behavior in the Middle East and North Africa is compared with other political actors in the same region rather than with those in mature democracies in Western Europe and North America. Samir Amghar (2008: 75f.), for example, emphasises the need to consider the dynamic character of Islamism and to avoid essentialist definitions in order not to ascribe to actors opinions that they do not necessarily have. With the Brotherhood's history now almost spanning a hundred years with local branches, or independent groups 
inspired by it, in most states in the Middle East and North Africa, contradicting evaluations of the movement can find empirical support in different countries and time periods. Carrie Wickham (2013: 2) argues that generalisations of the Brotherhood as for or against democracy miss the movement's internal debates and inconsistencies.

Since its foundation in Egypt in 1928, the Muslim Brotherhood has spread across the Middle East and North Africa through local branches and ideological influence. However, it is hard to define a coherent Brotherhood ideology because of the movement's tendency to adapt its message and policy to sociopolitical circumstances. This article will present an overview of the various directions the Brotherhood has taken at different periods of time and in different countries in the Middle east and North Africa.

\section{The Egyptian Mother Branch}

The Muslim Brotherhood was founded in the city of Ismailia, Egypt, in 1928 by Ḥasan al-Bannā (1906-1949), schoolteacher and son of a Ḥanbalī imān and author of Șūfi texts, Shaykh Aḥmad 'Abd al-Raḥmān. Al-Bannā's education included both government and Qur'ānic education as well as tutelage under Șüfi masters (Krämer 2015: 202). In his youth, he was influenced by nationalist and anti-colonial ideas and the Islamic reformist movement, 'iṣläh, that emerged during the second half of the nineteenth century with leaders such as Jamāl al-Dīn al-Afghānī, Muḥammad 'Abdu, and Rashīd Riḍā. Al-Bannā and many of the members of the Brotherhood belonged to an emerging and newly urbanised educated lower middle class. His criticism was not only directed at the British colonial regime but also at the Egyptian upper classes' monopoly on economic and political influence. Brynjar Lia has described the Brotherhood as part of the emergence of modern mass politics in Egypt in the 1930s (Lia 2006: 13; Mitchell 1993: 321).

Al-Bannā's initial focus was to educate a new generation of Muslims in what he considered to be a correct understanding of Islam. Since then, the concept of tarbiyya, (education), has been central to the movement (Lia 2006: 37). According to Brynjar Lia, the politisation of the movement's message began in earnest with a speech of al-Bannā in 1938 in which he emphasised Islam as an all-encompassing system that covers all areas in life. He contrasted this understanding with what he called "traditional Islam," which he described as submissive and serving colonial interests (Lia 2006: 202).

Even though al-Bannā called for an Islamic state, he never specified what this meant. He talked about social justice, redistribution of resources, an 
elected assembly and a constitution that limits the prerogatives of powerholders and make them accountable to the people. An Islamic constitution would also, according to al-Bannā, limit lawmakers' authority to make laws that violate Islamic rules and norms. He had an ambiguous view on party politics. On the one hand, he criticised party politics with the pejorative term hizbiyya, 'partyism', on the other he and other members contested for parliament on different occasions during the 1940s. The first time when he contested elections, he gave in to pressure from the government and withdrew his own and other members' candidacies and supported the Wafd party, thereby accepting the result of rigged elections (Mitchell 1993: 219, 309).

Al-Bannā's willingness to bargain caused frustration among many members who began to view revolutionary action as the only way for change. Already in the 192os the two biggest political parties, the Wafd and the Young Egypt, had their own militias that clashed with each other. Another factor was the Palestinian uprising 1936-1939. The Brotherhood was only one among several Egyptian groups that sent voluntary fighters to Palestine. In 1940, the Brotherhood's military wing, al-tanzìm al-khāsș, 'The Special Organisation', was formed. Lia explains this as an attempt to diffuse the pressure from radicalised members and at the same time ensure that the violence did not escalate out of control (Lia 2006: 180, Mitchell 1993: 3off). However, during the 1940s al-Bannā was increasingly challenged by the leaders of the armed wing to the extent that it appeared uncertain who really led the movement.

In December 1948, the Egyptian government dissolved the Brotherhood with a decree and two months later, in February 1949, al-Bannā was assassinated by unknown perpetrators. Because of internal division, it took two years before Ḥasan al-Huḍaybī (1891-1973) was elected as a new leader as a compromise candidate. This prominent jurist had until then not even been a member of the movement. His task was to consolidate the movement internally and to negotiate with the government and the royal court and later with the Free officers who took power in 1952. Al-Hudiaybì also had to face challenges from radicalised members whose most prominent ideologue was to be Sayyid Quṭb (1906-1966).

Sayyid Quțb is, with al-Bannā, the Brotherhood's most well-known thinker. It should however be stressed that he was never the leader of the movement, but the ideologue of a secret internal group within it, called Organisation 1965, which gathered members who had been radicalised in the prisons. Barbara Zollner divides Qutb's career into three phases. During the 1930s and 1940s he was a secular literary author and critic. After a stay in the United States 19481950, where he was sent by the Egyptian ministry of education to study the American education system, his ideas had a more Islamic color and after his 
return to Egypt he joined the Brotherhood and became the editor of its weekly al-Ikhwan al-muslimin. Quṭ now argued that a secular division of state and religion is a result of a specific Western historical development which is foreign for Muslim societies. During this phase, his texts focused on social justice from an Islamic perspective and it was during this period he published his book Social Justice in Islam (Zollner 2009: 51ff).

The third and last phase began with his first arrest in 1954. Under the influence of the Pakistani thinkers Abū l-Ḥasan al-Nadwī and Abū l-A'lā Mawdūdī, he formulated his theory that political sovereignty, hâkimiyya, is located solely with God and that the society and political system in Egypt had relapsed into jāhiliyya, 'ignorance of Islam'. Hence, jāhiliyya, traditionally referring to the Arabs' ignorance of Islam before the revelation of the Prophet Muhammad, for Quț became a timeless concept for criticising conditions in contemporary society. He argued that the Islamic profession of faith, shahāda, is a call for political action and that Muslims who do not combine faith with action are guilty of unbelief, kufr. Hence, Quț embraced the idea of takfir, to designate as unbelievers other Muslims, who disagree with one's own interpretation, a practice that has always been controversial among Muslim scholars. These ideas were laid out in the book Milestones which, according to Zollner, probably was written as an ideological program for members in the Organisation 1965. Quțb's ideas became a source of inspiration for the Brotherhood's armed wing and later also for well-known jihadist ideologues such as al-Qā̄ida's current leader 'Ayman al-Zawāhirī; and the former spokesperson for the Islamic State 'Abū Muhammad al-'Adnānī. Both al-Qā'ida and the Islamic State usually makes an explicit exception for Quṭb when they accuse the Brotherhood of apostasy because of its recognition of parliamentary democracy (Zollner 2009: 52ff).

In 1977, a book entitled Du'àt lā quḍāt (Preachers not Judges) was published under the name of the Supreme Guide Hasan al-Hudaybì. According to Zollner, it had been completed and distributed to members already in 1969 and was the result of a collective work that included Muslim scholars at the alAzhar University as well as members in the Brotherhood's leadership. Several of the latter would eventually succeed each other as the movement's supreme guide. The purpose of the book was to consolidate al-Hudaybìs authority over the Brotherhood and to refute Quṭb's jihadist theory, although without naming him. Quṭ's reinterpretation of the concept jāhiliyya is rejected with the argument that Muslims never lost the truth after Muhammad's revelation. The establishment of an Islamic state, in which Islamic law is applied, is described as a secondary matter. What is central is instead that individual Muslims apply Islam in the own lives. Political ruler should be obeyed, even 
if they violate Islamic rules, and active opposition should only be a last resort (Zollner 2009: 64ff).

Al-Huḍaybī did not have the charisma of al-Bannā and Quṭb and is described by Mitchell as a weak leader with a great deal of responsibility for the near destruction of the Brotherhood in 1954 (Mitchell 1993: 300). Zollner, on the other hand, claims that it is his ideas, to a significantly greater extent than the ideas of both al-Bannā and Quṭb, that have laid the foundation for the movement's development since the 1970s (Zollner 2009: 146). When Anwar Sadat succeeded Nasser as president in 1970, a great number of the movement's members were released from prison and the Brotherhood was permitted to resume its activity. Al-Huḍaybī passed away in 1973 and was succeeded by 'Umar al-Tilmisāni, who continued the former's policy of nonviolent and gradual Islamisation of society. In the 1970s, a number of Islamist groups emerged at Egyptian universities. These students were often influenced by Sayyid Quțb and several of these groups eventually developed into armed jihadist groups. However, others joined the Muslim Brotherhood, where they were exposed to the reformist line of al-Huḍaybì and al-Tilmisānī. It was from this generation the leaders of the Brotherhood's reformist wing in the 199os sprang, who demonstrated a more unreserved support than al-Huḍaybī and al-Tilmisānī for a democratic multiparty system and the rights of religious minorities (Zollner 2009: 146).

In the 1980s, The Muslim Brotherhood appeared as the strongest opposition movement in Egypt and an internal discussion on whether to establish a political party began, a discussion that would continue until the fall of President Hosni Mubarak in 2011. The reformist wing advocated a political party while the conservative wing advocated a focus on $d a^{\prime} w a$, missionary activities. Already in 1996 Hizb al-Wasat, 'the Center Party', had been formed with the participation of some members of the reformist wing as well as non-members of the Brotherhood. The new party met resistance from both the regime and the Brotherhood leadership, which excluded the members who persisted to stay within the party. In 2007, the Brotherhood leadership and the reformist wing presented two party programs, still without having founded a party. Both programs demanded democratic reforms but the leadership's version suggested a religious expert council with veto power over legislation and a provision that the chief of state must be male and Muslim. In the autumn 2009, the General Guide Muhammad Akif resigned. This was the first time anyone had resigned from this position: the previous general guides having stayed until death. Muhammad Badi', a representative for the conservative wing, was elected as his successor and in the election to the Bureau of Guidance the reformist representatives lost their seats. 
The new conservative leadership declared that it had no intention to form a political party and it was now expected the Brotherhood would distance itself from political activity. When street demonstrations against the regime broke out in the beginning of 2011 the Brotherhood leaders initially were cautious. However, younger members pressured them to back the protests which eventually led to the toppling of President Mubarak. The Brotherhood now finally formed a political party, the Freedom and Justice Party, and forbade members to join rival parties. The party gained 43.4 per cent of the votes in the election to the constituent assembly. In 2012 the Brotherhood's candidate Muhammad Mursi won the presidential election with a narrow margin over the military's candidate but was toppled by the military only a year later.

\section{3}

\section{The Structure of the Brotherhood}

The precise form of the Brotherhood's structure has varied over time but has to a great extent remained the same since the 1940s. On the grassroot level the movement is divided into usar, 'families', of about five members who are in intensive contact with each other to strengthen each other's belief. This is the central level for ideological training and cohesion through common prayer. A handful of families form a shu' $b a$, 'division'. Three to four divisions form a mantiq, 'district'. Each Egyptian province has an administrative bureau that gathers all the districts in the province (al-Anani 2016: 103ff).

On the national level there is a majlis al-shūrā, shürā council, which is the decision-making organ of the movement. It has ninety members elected from the provinces. There is also a guidance bureau with sixteen members elected from the shürā council. The guidance bureau serves as the executive body. The Brotherhood's leader has the title al-murshid al-'amm, the 'General Guide'. He is elected by the shürā council, after having received a bay'a, oath of allegiance, from all members:

I contract with God ... to adhere firmly to the message of the Muslim brothers, to strive on its behalf, to live up to the conditions of its membership, to have complete confidence in its leadership and to obey absolutely, under all circumstance ( $f$-l-manshat wa-l-makra). I swear by God in that and make my oath of loyalty to Him. Of what I say, God is Witness. quoted in MITCHELL 1993: 165

However, there is disagreement among members what this oath really means and to whom or what the allegiance is pledged. Some argues that the loyalty 
is towards the Brotherhood's principles rather than the individual leader. The oath has been criticised by some members for being used to silence internal opposition (al-Anani 2016: 124f; Mitchell 1993: 304).

In the 195os, exiled members of the Brotherhood, mainly from Egypt but also from Syria and Iraq, found refuge in Saudi Arabia and positions at the newly opened universities there (Lacroix 2011: 37ff). During the 1950s and 1960s at least four rival Muslim Brotherhood groups were established in the kingdom and they never managed to unite under one national organisation. In spite of contacts with the Egyptian mother organisation, the Saudi members never swore an oath of allegiance to its leader. One problem for the Saudi Brotherhood has been the deep suspicion within the Wahhābi tradition against parties and groups as creating division among believers (Lacroix 2011: 62ff).

More important than these groups have been various ideologies that emerged as a result of the meeting between the internal Wahhābi tradition and foreign Muslim Brothers and which with time would challenge the Saudi political system. Jihadists, whose ideology is based on a selective reading of Sayyid Quțb, turned against the Saudi regime when American troops were allowed on Saudi soil during the Gulf War in 1991. This war also led to the emergence of a movement called al-Ṣahwa al-Islämiyya, 'the Islamic awakening', or The Sahwa, which demanded the evacuation of American troops but also political reforms, demands formulated in public petitions. In a country where any public criticism of the king is considered as treason, this led to a swathe of mass arrests in 1994 that lasted for five years. When the country was shaken by a waves of jihadist attack in 2003 and 2004, some of these representatives of The Sahwa were used to spread a nonviolent interpretation of Islam and in rehabilitation programs for jihadists (al-Rasheed: 2007: 82f, 170).

The Arab Spring 2011 was met with enthusiasm among many representatives of The Sahwa and led to a new flood of public petitions demanding political reforms and when the Egyptian President Mursī was toppled by the military in 2013 they condemned it as a violation of the popular will, which implicitly challenged the Saudi monarchical system (Al-Rasheed 2015: 35ff, 88ff). In the Spring of 2014, the Brotherhood was banned and categorised as extremist and a terrorist organisation.

The Jordanian branch of the Muslim Brotherhood was founded in 1945 . The first decades the movement was allied with the royal house against the leftist opposition (Wickham 2013: 197). When King Hussein lifted the state 
of emergency, which had been introduced after the Israeli occupation of the West Bank in 1967, and allowed political parties, the Brotherhood formed the party Islamic Action Front in 1992 and began during the 1990s to stress Islam's compatibility with democracy (Wickham 2013: 209). According to Roald, there was a swift change after the political opening in 1992. Before that year, representatives of the Brotherhood had talked about a specific form of Islamic democracy, distinctive from Western democracy, with reference to the Islamic concept shürā, counsel, which they claimed meant that the ruler should listen to religious scholars. After 1992, the standard answer was instead to identify shürā with Western democracy. In this period the Brotherhood also had begun to cooperate with secular leftist parties in opposition to a conservative government. In 2007, the same leaders had substituted the loanword dimuqratiyya for shürā (Roald 2012a: 75; Roald 2012b: 99f). However, the party took a more conservative position on issues relating to reforms of women's position. Wickham explains this with the party's internal democratic structure which made the leaders more attentive to tribal norms among a conservative public opinion, which prompted dissatisfied members to leave in 2000 to form the more reformist Wasat party (Wickham 2013: 219ff).

After the Second World War, a branch of the Muslim Brotherhood was established in Jerusalem. When the state of Israel was proclaimed in 1948, the Brotherhood on the West Bank was incorporated into the Jordanian branch. While the Jordanian Brotherhood operated as a loyal opposition to the monarchy, the branch in Gaza, now under Egyptian rule, became involved in the conflict between the regime and the Egyptian Brotherhood. With the Israeli occupation of the West Bank and Gaza in 1967 the two branches approached each other again. Until the first Intifada in 1987, the Palestinian Brotherhood focused on $d a^{i} w a$, charity, and local politics, leaving militant resistance to secular groups. This prompted dissatisfied members to leave, some of whom participated in the formation of Fatah in 1965 while others formed armed Islamist groups, such as Islamic Jihad at the end of the 1970s (Gunning 2007: 27f; Seurat 2015: 14f).

In Israel, the occupation of the West Bank in 1967 led to a revival of Islam with a renewed access to religious scholars educated on the West Bank. In 1984, the Islamic Movement was founded under the leadership of Shaykh Abdallah Nimr Darwish. He was newly released from a prison term for having being member in an armed group, but he now rejected violence and advocated support for Palestinian, Muslim, and Arab identity within the legal framework in Israel. The movement participated in local elections in 1984 and 1989 but split in 1996 into a northern and a southern branch. Under the leadership of Darwish, the southern branch joined other Palestinian parties in the Arab 
Unity List, while the northern branch advocated a boycott of the Knesset, arguing that campaigning for it would imply a recognition of the Israeli state's legitimacy. Both branches reject violence, but the latter has used a harsher rhetoric towards Israel and occasionally defended Ḥamās (Göndör 2012: 53ff; Rosmer 2012: 325ff; Daoud 2016: 22ff).

The expansion of Israeli settlements on the West Bank and Gaza led to the first Intifada in 1987 and to impatience among younger members of the Brotherhood with the movement's inactivity in the resistance. In 1987, Harakat al-Muqāwama al-Islämiyya (The Islamic Resistance Movement), with the acronym Ḥamās, was founded by older and younger leaders in Gaza. The younger leaders were allowed to form an armed branch of resistance separate from the Brotherhood (Gunning 2007: 39; Seurat 2015: 15f).

The Charter of Ḥamās, written by a young leader in 1988, defines Palestine as an Islamic charity, waqf, thereby describing resistance against the Israeli occupation as a religious duty. From this follows that the land is to be governed by Islamic law and Christians and Jews are allowed to live there as dhimmis, 'protected people', under Muslim sovereignty. The Charter also blames crusaders and Zionists for obstructing the establishment of an Islamic state and even mentions a Jewish world conspiracy with a reference to the Protocols of the Elders of Zion. These formulations have not only met external criticism but also from some leaders within Hamās, while other leaders have tried to ignore the text and describe it as of secondary importance or no longer relevant (Charter of Ḥamās 1996 [1988]; Seurat 2015: 22).

Since its foundation in 1987, Hamās has alternated between violence and diplomacy to achieve its interests. Between 1994 and 2005, the movement performed a number of suicide attacks in Israel. Since then, the use of violence has been limited to rocket attacks on villages near Gaza and attacks on Israeli soldiers. Ḥamās has offered Israel limited truces and introduced unilateral ones when it has considered it politically motivated (Gunning 2007: 195; Hroub 2010: 57; Brenner 2017: 3of).

In 2005, Hamās decided to participate in the elections to the Palestinian Legislative Assembly, which it surprisingly won. In the election campaign its political party toned down the religious rhetoric for the benefit of a more nationalist language. The election platform did not mention the idea of an Islamic state but did contain a passus that sharita should be the main source of legislation (Hroub 2010: 20, 40, 136ff; Seurat 2015: 48f; Brenner 2017: 3).

While Hamās was founded by members of the Muslim Brotherhood, the movements do not have formal ties and Hamās has described the link differently according to the context. When Hamās' external leadership was based in Amman, Jordan, in the 199os, there was a rapprochement towards 
the Jordanian Brotherhood but when it moved to Syria, where membership in the Brotherhood entails capital punishment, the ties were dissolved. When Muhammad Mursī was elected president of Egypt in 2012, the ties were strengthened once again and Ḥamās added the phrase 'section of the Muslim Brotherhood' to its official name. After the military coup that toppled Mursī, Hamās distanced itself from the Brotherhood (Seurat 2015: 19, 95).

In May 2017, Hamās published a new document with general principles and policies in which Ḥamās is described as a national Palestinian liberation and resistance movement with Islam as a frame of reference. The Muslim Brotherhood is not mentioned and the founding Charter's references to the Protocols of the Elders of Zion has been replaced with assertions that the enemy is 'the Zionist project', not Jews because of their religion. In an ambiguous formulation the document rejects any concession of the historical Palestine, 'from the river to the sea', while at the same time hinting to a sovereign Palestine state within the 1967 borders.

The Syrian branch of the Muslim Brotherhood was founded in 1945. During the two first decades, it advocated parliamentary democracy and the recognition of the rights of religious minorities in more unambiguous terms than the Egyptian mother movement. The first leaders, Muștafā al-Sibāī and Issam al-Attar, claimed that Islam only provides general principles for governance, leaving details to human reason (Lefèvre 2013: $23 \mathrm{ff}, 86$ ).

After the Baathist coup in 1963, a jihadist wing within in the Brotherhood emerged in Hama, led by Marwan Hadid. Several members began to condemn the regime in sectarian terms because of the Alawì origins of several military leaders in the new regime (Lefèvre 2013: 72ff, $97 \mathrm{ff}$ ). Unrest and mass arrests during the 1970s culminated in a massacre on 83 'Alawite cadets at the Aleppo artillery school in 1979. The following days, thousands of members of the Brotherhood were arrested and tortured. In 1980, a law was passed banning membership in the movement under the penalty of death. In 1984, the regime cracked down on a rebellion in Hama by bombing the city, which resulted in between 10,000 and 40,000 deaths (Lefèvre 2013: 125ff). Surviving members of the armed wing fled the country and several of them were to join al-Qấida later (Lefèvre 2013: 138). At the end of the 198os, the moderate wing regained dominance within the Brotherhood. It initially attempted to bargain with the regime but after 2000 initiated a dialogue with the secular opposition. In 2004, the Brotherhood published a political program demanding free and transparent elections and assured that it would accept a Christian or a woman as president if this would be the result of elections. When the rebellion against the regime broke out in 2011, which was soon to develop into a civil war, the Brotherhood joined the Syrian National Council, while groups 
within the former armed wing joined al-Qā'ida's Syrian wing, the Nusra Front (Lefèvre 2013: 87f).

In Algeria in 1992, the Islamic Salvation Front (FIS) was on the brink of becoming the first Islamist party in the Middle East and North Africa to come to power in free elections. It had gained 55 per cent of the votes in the local elections in 1990 and 44 per cent in the first round of elections for the presidency in 1991. However, the military intervened, deposed the president, cancelled the second round of elections, and banned the party. This was the beginning of a bloody civil war that cost an estimated 200,00o lives between 1992 and 1999. FIS established an armed wing, AIs, which mainly attacked the police and military. However, a new armed group, which eventually would develop into al-Q̄âiida in the Maghreb, also attacked civilians. It is still discussed to what extent groups within the regime were involved in the violence against civilians (Utvik 2016: 114ff).

FIS was founded in 1989 by members in various Islamist groups. However, some of the leader refused to join the new party. Ahmad Sahnoun founded the Islamic Nahḍa and Mahfuz Nahna the Movement for an Islamic Society (with the acronym HAMAS, without any relation to the Palestinian movement). Both were inspired by the Muslim Brotherhood. According to Bjørn Utvik, Nahna was a member in the international organisation of the Brotherhood and Sahnoun's Nahḍa had a structure similar to that of the Brotherhood with a base of families where the members were socialised in the party's ideology (Utvik 2016: 115ff; Boubekeur 2009: 168ff; Willis 1998: 17off).

While the banned Fis went underground, both Nahḍa and HAMAS operated as a legal opposition during the civil war in the 199os. Nahḍa had made more clear demands for the Islamisation of legislation and enforcing Islamic norms in society, thus attracting members from FIS. HAMAS entered a closer cooperation with the regime and even participated in some governments between 2002 and 2007. The Algerian case illustrates how groups ideologically influenced by the Muslim Brotherhood in some circumstances may end up on different side, even in a civil war (Utvik 2016: 116; Boubekeur 2009: 169f; Willis 1998: $57 \mathrm{ff})$.

In Tunisia, the Islamic Tendency Movement (harakat al-ittija hal-islami) was founded in the 1981 with the aim to Islamise society and counter Western influences on Tunisian society. After president Bourguiba had been toppled by Zine el Abidine Ben Ali in 1987, a short period of political opening followed, and the movement changed its name to al-Nahḍa ('Renaissance'). In 1989, the most prominent of its leaders, Rachid Ghannouchi, was forced into exile in London, where he gradually began to emphasise Islam's compatibility with democracy and human rights. He appears to the earliest Islamist leader who advocated 
that women could be chiefs of state. While Ghannouchi in his youth had been an admirer of Sayyid Quțb, he now talks about popular sovereignty instead of God's sovereignty. He describes Islam as a normative system which provides a spiritual and moral dimension to what he considers the purely materialistic basis of Western democracy. This combination of Islam and democracy has made Ghannouchi a central point of reference for many Brotherhood sympathisers in Europe (Roald 2001: 192f). After the fall of Ben Ali in 2011, al-Nahḍa has been part of succeeding governments. In 2016, the party declared that it considered itself as a purely political party and did not identify as Islamist.

\section{Conclusion}

The hierarchical structure of the Muslim Brotherhood has proved to be both a strength and a liability. It has helped to movement to survive under authoritarian regimes, but the emphasis on members' obligation to obey the leadership has not prevented factionalism and splits within the movement, with some banished members still enjoying a status as its most prominent thinkers. Strategically, Brotherhood branches have been involved in both armed and peaceful resistance, as well as being coopted by authoritarian regimes. Hence, the Brotherhood's ideology is best seen as fluid and adaptable to different sociopolitical circumstances, having produced militant jihadist ideas as well as defenses for democratic values.

\section{References}

Al-Anani, K. 2016. Inside the Muslim Brotherhood. Religion, Identity, and Politics. New York: Oxford University Press.

Al-Rasheed, M. 2007. Contesting the Saudi State. Islamic Voices from a New Generation. Cambridge: Cambridge University Press.

Al-Rasheed, M. 2015. Muted Modernists. The Struggle Over Divine Politics in Saudi Arabia. London: Hurst.

Amghar, S. 2008. "Europe puts Islamists to the Test: The Muslim Brotherhood (France, Belgium and Switzerland)." Mediterranean Politics. 13:1, 63-77.

Besson, S. 2005. La conquête de l'Occident. Le projet secret des islamistes. Paris: Seuil.

Boubekeur, A. 20o9. "Islamist Parties in Algeria. Toward a Political Professionalization?" In M. Salih ed., Interpreting Islamic Political Parties. New York: Palgrave, 167-19o.

Brenner, B. 2017. Gaza Under Hamās. From Islamic Democracy to Islamist Government. London: I.B. Tauris.

Charter of Ḥamās. 1996. TfMS —-Tidskrift för mellanösternstudier nr. 1: s. 14-24. 
Daoud, A. 2016. "Islamism, Nationalism and Modernization: The Case of the Islamic Movement in Israel." Politics, Religion \& Ideology. 17:1, 18-32.

Göndör, E. 2012. Muslims.ka kvinnor i Israel. Religionens roll i vardagslivets förflyttningar. Lund: Lund Studies in History of Religions.

Gunning, J. 2007. Hamās in Politics. Democracy, Religion, Violence. London: Hurst \& Company.

Hroub, K. 2010. Hamās. A Beginner's Guide. 2nd ed. London: Pluto.

Johnson, I. 2010. A Mosque in Munich. Nazis, the CIA, and the Rise of the Muslim Brotherhood in the West. New York: Mariner Books.

Krämer, G. 2015. "Making Modern Muslims: Islamic Reform, Hasan al-Banna, and the Egyptian Muslim Brotherhood." In S. Trakulhun and R. Weber eds, Delimiting Modernities: Conceptual Challenges and Regional Responses. London: Lexington, 197-214.

Lacroix, S. 2011. Awakening Islam. The Politics of Religious Dissent in Contemporary Saudi Arabia. Cambridge MA: Harvard University Press.

Lefèvre, R. 2013. Ashes of Hama. The Muslim Brotherhood in Syria. London: Hurst.

Lia, B. 2006. The Society of the Muslim Brothers in Egypt. The Rise of an Islamic Mass Movement 1928-1942. Reading: Ithaca Press.

Mitchell, R.P. 1993 [1969]. The Society of the Muslim Brothers. New York: Oxford University Press.

Roald, A. 2012a. "Democratisation and Secularisation in the Muslim Brotherhood: The International Dimension." In R. Meijer and E. Bakker eds, The Muslim Brotherhood in Europe. London: Hurst, 71-88.

Roald, A. 2012b. "Individualisering och sekularisering av det islamiska budskapet? Utveckling av politiska begrepp hos Muslimska brödraskapet i Jordanien." In J. Otterbeck and L. Stenberg eds, Islamologi. Studiet av en religion. Falun: Carlssons, 88-110.

Roald, A. 2001. Women in Islam. The Western Experience. New York: Routledge.

Rosmer, T. 2012. “Resisting 'Israelization': The Islamic Movement in Israel and the Realization of Islamization, Palestinization and Arabization." Journal of Islamic Studies. 23:1, 325-358.

Seurat, L. 2015. Le Hamās et le monde. Paris: CNRS.

Utvik, B.O. 2016. Islamismen. 2nd ed. Bergen: Fagbokforlaget.

Vidino, L. 2010. The New Muslim Brotherhood in the West. New York: Columbia University Press.

Wickham, C.R. 2013. The Muslim Brotherhood. Evolution of an Islamist Movement. New Jersey: Princeton University Press.

Willis, M. 1998. "Algeria's other Islamists. Abdallah Djaballah and the Ennahda movement." The Journal of North African Studies. 3:3, 46-70.

Zollner, B.H.E. 20o9. The Muslim Brotherhood. Hasan al-Hudaybi and Ideology. New York: Routledge. 